\title{
Worse quake to come, Indonesia warned
}

A week after a series of powerful earthquakes rocked Indonesia, killing more than 20 people, geologists are warning that "the big one" may be yet to come. The region might still hold enough energy to release a magnitude-9.0 tremor that could produce a deadly tsunami, echoing the 2004 tsunami that killed more than 230,000 people in southeast Asia.

The trio of quakes, of magnitudes 8.4, 7.9 and 7.0, occurred off the coast of Padang in southwest Sumatra on 12 and 13 September, along a subduction zone where the Australian tectonic plate dives under the Sunda plate. The plates are sliding past each other, but in some patches they stick, building pressure, which is released when the plates slip in an earthquake. Last week's earthquakes released pressure from a 700-kilometre-long region, known as the Mentawai section, which had been building since the last quake, an event of magnitude 8.6-8.9 in 1833.

Kerry Sieh, an earthquake geologist at the

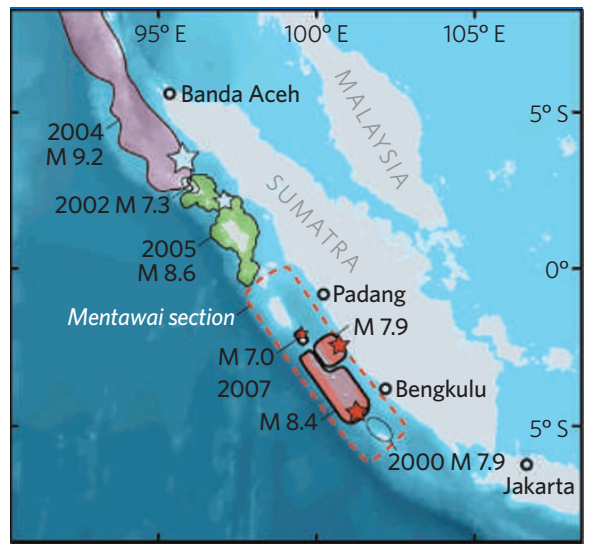

A magnitude-9.0 quake is predicted to hit the top of the Mentawai section, left unruptured last week.

California Institute of Technology in Pasadena, has spent the past 15 years studying the history of Indonesian earthquakes from the patterns the tremors leave in coral growth. His data suggest that this area has ruptured every 200 to 230 years since the fourteenth century.

Based on Sieh's study of the uplift of fossil corals, a preliminary analysis suggests that last week the plates slipped far less (around 2 metres) than they did in 1833 (10-18 metres). If that is the case, not all the pressure may have been released, and part of last week's rupture zone could 're-rupture' in conjunction with a 200-kilometre patch off the coast of Padang (see image) that has not ruptured since 1797 . That would produce a magnitude-9.0 quake, he says - enough to spawn a deadly tsunami.

Jim Mori, an earthquake specialist at Kyoto University's Disaster Prevention Research Institute, says Sieh's 'seismic gap' theory is plausible. "It is similar to the geological trough at Nankai in Japan in that earthquakes are now expected where they have not occurred in a long time," he says.

David Cyranoski

See News Feature, page 278.

\section{Gene therapy might not have caused patient's death}

A patient with arthritis who died in July during a gene-therapy trial may have succumbed to an infection she had before the viral vector was administered, experts said on Monday at a meeting of an advisory panel in Bethesda, Maryland, investigating the incident .

Little of the evidence presented to the panel seemed to indicate that the injected viral vector had a key role in 36-year-old Jolee Mohr's demise. Although DNA sequences from the vector were found in her liver and spleen, "the detection of the sample is very low and below the limit of quantification in these assays", said Jeffrey Bartlett, a member of the National Institutes of Health (NIH) Recombinant DNA Advisory Committee (RAC). "It really indicates the absence of ongoing replication of the vector in these tissues."

The panel is still awaiting the results of tests on Mohr's tissue samples, expected by December, and the results of blood studies looking for the vector and protein produced by the transgene. It will then reach a firmer conclusion about whether the gene therapy she received three weeks before her death was in any way responsible for it. But even with all the information in hand, "there will I think still be some uncertainty", said RAC chair Howard Federoff.

Mohr died on 24 July, 22 days after her right knee was injected with an adeno-associated virus (AAV) vector made by Targeted Genetics, a Seattle company. This vector was engineered to contain a gene for an anti-inflammatory protein, TNFR:Fc, which inhibits tumour-necrosis factor- $\alpha$ (TNF- $\alpha$ ). TNF- $\alpha$ causes inflammation in rheumatoid arthritis.

Autopsy results and the clinical history of the patient presented at the 17 September meeting indicated that the immediate cause of her death was massive bleeding of unknown origin in the tissue space behind the kidneys. This displaced her abdominal organs and ultimately compressed her lungs, making them unable to function. She was also overwhelmingly infected with histoplasmosis, an environmental fungus that can cause serious infections in immunocompromised individuals. She began to feel ill with fatigue and a low-grade fever three days before the gene therapy was administered, the panel heard.

TNFR:Fc suppresses the immune system, and so it is possible that the gene therapy caused the infection. However, the design of the trial, in which some patients were also taking similarly acting immunosuppressant drugs, means that it will be difficult to ascertain what caused the infection to take hold. Mohr was also taking a TNF- $\alpha$-inhibitor drug for the arthritis, which suppresses the immune system. Carol Kauffman, an infectious-disease specialist at the University of Michigan, Ann Arbor, told the panel that overwhelming histoplasmosis infection had killed several patients taking such TNF-inhibitory drugs.

Of the 871 gene-therapy trials registered with the $\mathrm{NIH}, 4 \%$ have used AAV. Officials at the NIH and the US Food and Drug Administration reported at the meeting that they had reviewed all the AAV trials to date and found no pattern of adverse events associated with AAV, or any increased incidence of adverse events compared with trials using other gene-therapy vectors. The trial Mohr took part in was unusual in that it involved repeated injections. It was halted after her death.

Meredith Wadman

Correction
In the News story 'Borysiewicz to
head UK medical council' (Nature
$\mathbf{4 4 9 , 1 2 1 ;}$ 2007), we misquoted
Colin Blakemore, chief executive
of the Medical Research Council
(MRC), in a way that suggested
he knew that there would be a
substantial increase in the MRC's
budget. Professor Blakemore
said that he hoped there would
be a substantial increase in the
MRC's budget, and points out that
he is not in a position to declare
a definite funding increase. We
apologize to Professor Blakemore.

